time and motion study. Colour film is being used in recording work carried out by the Lighting Section to render machine parts more easily distinguishable by painting them in contrasting colours; this should lead to a reduction of fatigue and an increase in efficiency of the machine operators. The Building Research Station aims at presenting information on new materials and methods to all who are in a position to influence the design and construction of buildings. Its films are, therefore, addressed to architects, surveyors, builders, technical staffs of local authorities and members of housing committees.

\section{Drainage Evolution in the Appalachians}

IT has long been agreed that, following the Appalachian Revolution, the divide between east- and west-flowing streams in that region was situated somewhere east of the present Great Valley in the crystalline rocks of Old Appalacia. To-day the divide is beyond the Ridge and Valley province in the Appalachian Plateau, eight miles or more to the west of the crystalline rocks. Over a broad belt there has been a reversal in the direction of the drainage. The sequence of events that led to this change is traced by H. D. Thompson in Annals of the New York Academy of Sciences (52, art. 2, pp. 31-62 ; 1949; 1.25 dollars). He traces a long and continuous series of river captures by which the main watershed has migrated eastward and led to a general eastward slope. In extending their headquarters westward, the east-flowing streams have been influenced greatly by structure. In general, they follow weak rock formation or local weaknesses in resistant rocks; also, it is noted that long low-gradient streams are at a disadvantage in competition with those having short steep courses.

\section{Chart for Spot Welding}

THE British Welding Research Association has just published a most ingenious chart for the spotwelding of mild steel. Given the thickness of the material which is to be joined, which varies from 0.01 to 0.05 inch, the chart, based somewhat on the lines of the slide rule, provides all the welding data required : weld time, weld current, tip diameter and minimum electrode-pressure can all be read off immediately. To those concerned with this type of welding it will be invaluable, and the principle on which it is constructed may well be applicable in other, and quite diverse, fields.

\section{London Conference on Optical Instruments}

Arrangements are well advanced for the London Conference on Optical Instruments which will be held at the Imperial College of Science and Technology, South Kensington, during July 19-26. The Conference is being arranged partly concurrently with the official sessions of the International Optical Commission (which will commence at the rooms of the Royal Society, Burlington House, on July 17 and will be attended by many delegates from overseas). In this way the conference will afford an opportunity of hearing speakers who are seldom able to visit Great Britain. There will be symposia on reflecting microscopes, phase-contrast microscopes, gratings and grating instruments, reflecting telescopes and spectrophotometers; and joint discussions with the international optical commission will deal with diffraction in optical instruments and new optical materials. There will be a number of miscellaneous invited papers on new instruments, such as that on the geodimeter by E. Bergstrand, etc. A number of social events are being arranged, including receptions by learned societies and excursions to optical firms and laboratories. An exhibition of optical instruments is being arranged by the Scientific Instrument Research Association. The list of speakers includes the following: Dr. F. Desvignes and Dr. M. Françon (France); Dr. R. Barer, Mr. J. Guild, Dr. H. H. Hopkins, Dr. E. H. Linfoot, Dr. H. W. Thomson and Mr. A. Warmisham (Great Britain); Dr. A. Bouwers (Holland); Prof. F. Scandone (Italy); Mr. E. Bergstrand and Dr. E. Inglestam (Sweden); Dr. W. Lotmar (Switzerland); Dr. S. S. Ballard, Mr. C. Bausch, Dr. D. S. Grey and Dr. R. Kingslake (United States). The general secretary of the Conference is Prof. L. C. Martin, Technical Optics Section, Imperial College of Science and Technology, London, S.W.7.

\section{Conference on Civil Engineering Problems in the Colonies}

A conference on "Civil Engineering Problems in the Colonies", on similar lines to that which took place in 1948, will be held at the Institution of Civil Engineers, Great George Street, Westminster, London, S.W.1, during July 3-7. The conference is désigned primarily to meet the needs of members of the Colonial engineering service and others engaged in civil engineering work in the Colonies. Besides visits and excursions to places of technical interest, the programme of the conference includes : a lecture on "Public Health Engineering" by Prof. Gordon M. Fair, of Harvard University; a technical session entitled "Engineering Research and the Colonial Engineer", at which papers will be given and discussed; and two other sessions at which papers will be given on railways and docks, harbours and wharves, tropical water supplies, low-cost roads and air-port construction. The conference is open to all who are interested. The capitation fee is $£ 55 s$. (£3 $3 s$. to corporate members and students of the Institution), with an extra fee of $£ 1$ ls. if accompanied by a lady. Further details can be obtained from the Secretary of the Institution.

\section{Announcements}

The Science Museum is presenting a special exhibition showing modern ideas of weather and meteorology, and their influence on everyday life, to mark the centenary of the Royal Meteorological Society. The exhibition will be opened by the Lord President of the Council on March 27 at 3 p.m., and will be available to the public during March 28June 25.

The Colorado School of Mines is offering a scholarship to a male student from Great Britain for the academic year 1950-51. The scholarship, which is renewable for a maximum of four years, covers tuition fees only and is worth 425-475 dollars a year. Further particulars may be obtained from the Deputy Cultural Relations Officer at the American Embassy, 5 Grosvenor Square, London, W.1, or from the Secretary, Association of Universities of the British Commonwealth, 5 Gordon Square, London, W.C.1, with whom applications must be lodged in triplicate by May 1.

Erratum. In the list of members of the Norwegian-British-Swedish Antarctic Expedition in Nature of January 7, p. 8, B. Ekström is incorrectly described as Norwegian; he is Swedish. 